\title{
PENGARUH MODEL PEMBELAJARAN KOOPERATIF TIPE BAMBOO DANCING PADA MATERI KOLOID TERHADAP HASIL BELAJAR SISWA KELAS XI SMAN 1 WANARAYA
}

\author{
The Effect of Bamboo Dancing Cooperative Learning Model on Colloidal \\ Material on the Learning Outcomes of Class XI Students of SMAN 1 \\ Wanaraya
}

Sri Lestari Ana, Novi Rahmawanti, Novrian Dony

Program Studi Pendidikan Kimia Fakultas Keguruan dan Ilmu Pendidikan Universitas Islam Kalimantan (Uniska) Muhammad Arsyad Al Banjari, Banjarmasin email: srilestariana67@gmail.com

\begin{abstract}
Abstrak. Proses pembelajaran merupakan kegiatan pelaksanaan kurikulum untuk mempengaruhi peserta didik demi tercapainya tujuan pendidikan yang telah ditetapkan. Pengajar memiliki peran yang sangat penting dalam meningkatkan hasil belajar siswa. Pengajar memerlukan inovasi-inovasi untuk dapat meningkatkan minat siswa terhadap pembelajaran kimia agar lebih menarik. Adanya keaktifan dan interaksi antar peserta didik dalam pembelajaran diharapkan pembelajaran lebih bermakna sehingga dapat meningkatkan hasil belajar peserta didik. Salah satu model pembelajaran yang dapat digunakan oleh pengajar untuk meningkatkan interaksi, keaktifan, dan pemahaman peserta didik didalam pembelajaran kimia adalah model pembelajaran kooperatif tari bambu (bamboo dancing). Pembelajaran kooperatif merupakan sistem kerja atau belajar kelompok yang terstruktur. Penelitian dilakukan di SMAN 1 Wanaraya kelas XI IPA A dan kelas XI IPA B dengan jumlah siswa 65 siswa, pada materi koloid tahun ajaran $2018 / 2019$. Berdasarkan hasil penelitian diperoleh nilai uji t-independen sebesar 0.01 kelas eksperimen dan 0.02 kelas kontrol $($ sig $<0.05)$
\end{abstract}

Kata kunci: kooperatif, Bamboo Dancing, Koloid.

\begin{abstract}
Learning process is an activity of implementing the curriculum to influence students for the achievement of educational goals that have been set. Teachers also have a very important role in improving student learning outcomes. Teachers need innovations to be able to increase students' interest in learning chemistry to make it more interesting. The existence of activeness and interaction of students are expected to be more meaningful in learning activities so that the learning outcomes of students may increase. One learning model that can be used by teachers to increase the activeness, interaction, and understanding of students in learning chemistry is the cooperative learning model of bamboo dancing (bamboo dance). Cooperative learning is a structured work system or group learning. The study was conducted at SMAN 1 Wanaraya class XI IPA A and class XI IPA B with a total of 65 students, on colloidal material in the 2018/2019 academic year. Based on the research results obtained t-independent test values of 0.01 experimental classes and 0.02 control classes ( sig <0.05)
\end{abstract}

Keywords: cooperative, Bamboo Dancing, Colloidal. 


\section{PENDAHULUAN}

Menurut Syaiful Bahri Djamarah dan Aswan Zain (2010), kegiatan belajar mengajar adalah proses mencapai tujuan pengajaran. Guru berperan sebagai pengajar yang memberikan pengajaran kepada peserta didik sehingga terjadi peningkatan dalam kemampuan belajar. Belajar mengajar merupakan kegiatan bernilai edukatif yang ditandai terjadinya interaksi antara guru dengan peserta didik. Interaksi dikatakan bernilai edukatif jika kegiatan belajar mengajar yang dilakukan dapat mencapai tujuan yang telah dirumuskan sebelum pembelajaran dilakukan. Guru merencanakan kegiatan pembelajaran secara sistematis untuk kepentingan pembelajaran. Selain siswa yang aktif didalam kegiatan pembelajaran, pengajar juga memiliki peran sangat penting didalam meningkatkan hasil belajar siswa. Pengajar harus dapat meningkatkan minat siswa dalam pembelajaran kimia agar lebih membuat siswa aktif. Apabila guru berhasil menciptakan suasana pembelajaranyang menarik agar peserta didik lebih percaya diri, termotivasi aktif serta terjadinya interaksi dalam proses pembelajaran, kemungkinan terjadinya peningkatan hasil belajar peserta didik akan semakin besar Dimyati dan Mudjiono (2006).

Berdasarkan hasil pengamatan di kelas XI IPA 1 dan XI IPA 2 SMA Negeri 1 Wanaraya diperoleh informasi bahwa hasil belajar peserta didik pada materi koloid untuk tahun ajaran 2018/2019 masih tergolong rendah, terlihat dari masih banyak peserta didik yang memperoleh nilai dibawah kriteria ketuntasan minimum (KKM) yang ditetapkan sekolah yaitu sebesar 60, sedangkan nilai rata-rata yang dicapai peserta didik adalah 55. Penyebab hasil belajar peserta didik rendah adalah peserta didik kurang aktif dalam proses pembelajaran serta kurangnya interaksi antara peserta didik dengan guru dan peserta didik dengan peserta didik. Kurang aktifnya peran siswa dalam belajar mengajar ini disebabkan oleh kecenderungan guru untuk mengutamakan aspek kognitif siswa, bukan interaksi antar siswa ataupun antara siswa dan guru (Sari, Akhyar, \& Wardhani, 2018). Penerapan model pembelajaran yang tepat diharapkan dapat menciptakan suasana peserta didik aktif sehingga terjadi interaksi diantar peserta didik dalam proses pembelajaran.

Adanya keaktifan dan interaksi peserta didik didalam kegiatan pembelajaran diharapkan kegiatan pembelajaran lebih bermakna sehingga hasil belajar dan hasil belajar peserta didik dapat meningkat menurut Made Wena (2010). Salah satu model pembelajaran yang dapat digunakan oleh guru untuk meningkatkan interaksi, keaktifan, dan pemahaman peserta didik didalam pembelajar kimia merupakan model pembelajaran kooperatif bamboo dancing. Bamboo dancing merupakan salah satu jenis metode pembelajaran yang digunakan dalam pembelajaran kooperatif untuk mengarahkan peserta didik terhadap materi yang akan dipelajari, sehingga mengajak siswa untuk belajar secara aktif. Menurut Istarani (2011), Metode pembelajaran tari bambu cocok digunakan untuk materi yang membutuhkan pertukaran pengalaman pikiran dan informasi diantar peserta didik. Model pembelajaran ini tergolong jarang digunakan dalam pembelajaran kimia karena sifatnya yang menekankan pada keaktifan siswa; model ini sedikit mirip dengan model jigsaw yang sebagian besar lebih banyak digunakan oleh peneliti terdahulu. Hal ini dikarenakan model pembelajaran tipe bamboo dancing memerlukan waktu yang lebih panjang dan memerlukan kelompok yang lebih besar (Shoimin, 2014). 
Model pembelajaran kooperatif bamboo dancing adalah model pembelajaran yang memberikan kesempatan bagi peserta didik agar lebih berperan aktif dan terjadi interaksi dengan peserta didik lainnya secara maksimal, sehingga terjadi pertukaran informasi antar peserta didik. Pembelajaran diawali dengan pengenalan topik dari guru. Guru menuliskan topik di papan tulis atau melakukan tanya jawab dengan peserta didik. Kegiatan tanya jawab dilakukan agar mengaktifkan struktur kognitif yang telah dimiliki peserta didik lebih siap menghadapi pelajaran yang baru menurut Istarani (2014). Interaksi didalam pembelajaran dikatakan maksimal apabila terjadi interaksi antara guru dengan peserta didik serta peserta didik dengan peserta didik lainnya, untuk mencapai tujuan yang telah ditetapkan bersama (Miterianifa, 2013). Model pembelajaran bamboo dancing ini diaplikasikan pada topik koloid yang pada umumnya pemberian materi koloid ini dilakukan dengan metode ceramah dimana guru lebih dominan dalam proses belajar mengajar (Sukarsih, Wardhani, \& Mashuri, 2018).

\section{METODE PENELITIAN}

Penelitian ini merupakan penelitian semu (quasy experiment). Penelitian ini bertujuan untuk meningkatkan hasil pembelajaran yang diinginkan dapat dicapai. Tempat penelitian adalah tempat yang digunakan dalam melakukan penelitian untuk memperoleh data bertempat di SMA Negeri 1 Wanaraya. Waktu penelitian adalah waktu berlangsungnya penelitian atau saat penelitian ini berlangsung. Penelitian ini dilaksanakan pada bulan mei 2019 sampai bulan juni 2019. Subyek penelitian adalah peserta didik kelas XI IPA 1 dan XI IPA 2 tahun 2019 pada mata pelajaran kimia materi koloid. Desain penelitian yang digunakan adalah non equivalence control grup design (Sugiyono, 2017)

Teknik yang digunakan adalah pretes dan post test menggunakan soal pilihan ganda sejumlah 20 soal. Pretest dilakukan sebelum proses pembelajaran dilaksanakan, hal ini dilakukan untuk mengetahui kemampuan awal siswa mengenai materi yang akan dipelajari terdiri dari soal pilihan ganda berjumlah 20 soal. Posttest dilakukan setelah kegiatan pembelajaran selesai, demi mengetahui hasil ketercapaian pemahaman siswa mengenai materi yang telah dipelajari terdiri dari soal pilihan ganda yang berjumlah 20 soal. Hasil pembelajaran tersebut dijadikan acuan perbandingan antara kelas eksperimen dan kelas kontrol.

Analisis Data yang digunakan yakni uji validitas instrumen dan uji reabilitas instrumen. Uji reliabilitas dalam penelitian ini penulis menggunakan metode Alpha Cronbach $(\alpha)$ dengan rumus sebagai berikut:

$$
\begin{aligned}
& R==R=\frac{N}{N-1}\left(\frac{S^{2}\left(1-\Sigma S_{i}\right)^{2}}{S^{2}}\right) \\
& \text { Dimana: } \\
& \alpha \quad=\text { Koefisien Reliabilitas Alpha Cronbach } \\
& \mathrm{N} \quad=\text { Varians skor keseluruhan } \\
& \mathrm{S} \quad=\text { Varians masing-masing item }
\end{aligned}
$$


a. Tingkat Kesukaran

$$
\mathrm{P}=\frac{B}{\mathrm{~B}}
$$

Yakni : p : Tingkat kesukaran, B: banyak peserta tes yang memberikan respon benar, $\mathrm{J}_{\mathrm{S}}$ : jumlah seluruh peserta tes

b. Daya Pembeda

$$
\mathrm{D}=\frac{B A}{J A}-\frac{B B}{J B}
$$

BA: Jumlah peserta kelompok atas dengan jawaban benar, BB: banyaknya peserta kelompok bawah yang menjawab soal dengan benar, JA: banyaknya peserta kelompok atas, JB:banyaknya peserta kelompok bawah.

\section{c. Uji Normalitas Data}

Dasar pengambilan untuk uji normalitas ini menggunakan software SPSS tipe v16.0. Kriteria pengujian normalitas sebagai Jika sig $<0,05$ maka data tidak terdistribusi normal, Jika sig $>0,05$ maka data terdistribusi normal

\section{d. Uji Homogenitas}

Pada penelitian ini menggunakan software SPSS tipe v16.0. kriteria pengujian homogenitas sebagai Jika sig $<0.05$ data tersebut tidak homogen, Jika sig $>0.05$ data tersebut homogen.

\section{e. Uji Hipotesis}

Penelitian ini menggunakan uji t-independent dengan menggunakan software SPSS tipe v16.0. kriteria pengujian uji hipotesis tse t sebagai Jika sig $>0.05 \mathrm{H} 0$ diterima, H1 ditolak, Jika sig < 0.05 H0 ditolak, H1 diterima.

\section{HASIL PENELITIAN DAN PEMBAHASAN}

Tabel 1. Nilai rata-rata pretes dan post test

\begin{tabular}{|l|l|l|}
\hline Sampel & pretest & Post test \\
\hline Kelas eksperimen & 55.57 & 85.00 \\
\hline Kelas kontrol & 56.57 & 80.00 \\
\hline
\end{tabular}

Tabel 2. Hasil uji normalitas

\begin{tabular}{|l|l|l|l|}
\hline Sampel & sig & $\alpha$ & Hasil \\
\hline Kelas eksperimen & 0.07 & $>0.05$ & Normal \\
\hline Kelas kontrol & 0.200 & $>0.05$ & Normal \\
\hline
\end{tabular}


Tabel 3. Hasil uji homogenitas

\begin{tabular}{|l|l|l|l|}
\hline Sampel & sig & $\alpha$ & Hasil \\
\hline $\begin{array}{l}\text { Kelas } \\
\text { eksperimen }\end{array}$ & 0.67 & $>0.05$ & Homogen \\
\hline Kelas kontrol & 0.67 & $>0.05$ & Homogen \\
\hline
\end{tabular}

Tabel 4. Hasil uji t-independent

\begin{tabular}{|l|l|l|l|}
\hline Sampel & sig & $\alpha$ & Hasil \\
\hline $\begin{array}{l}\text { Kelas } \\
\text { eksperimen }\end{array}$ & 0.01 & $<0.05$ & diterima \\
\hline Kelas kontrol & 0.02 & $<0.05$ & diterima \\
\hline
\end{tabular}

Hasil penelitian menunjukkan terjadi peningkatan hasil belajar peserta didik melalui penerapan model pembelajaran kooperatif bamboo dancing pada pokok bahasan teks faktual ilmiah. Penerapan model pembelajaran kooperatif bamboo dancing pada proses pembelajaran dilakukan pada kegiatan inti. Penerapan model pembelajaran kooperatif bamboo dancing diterapkan pada kelas XI IPA 1 dan XI IPA 2 SMA Negeri 1 Wanaraya.

Penerapan model pembelajaran kooperatif bamboo dancing pada materi koloid dapat meningkatkan hasil belajar peserta didik karena dapat memotivasi peserta didik untuk lebih aktif didalam proses pembelajaran dan terjadi interaksi antara peserta didik secara maksimal. Menurut Wina Sanjaya (2009) proses pembelajaran dikatakan berhasil apabila peserta didik mempunyai motivasi didalam belajar.

Berdasarkan pengamatan yang dilakukan peneliti saat penelitian, peserta didik sangat antusias dan saling mengemukakan pendapatnya didalam berdiskusi. Guru mengarahkan jajaran kelompok pertama bergeser ke kanan sehingga terbentuk pasangan diskusi yang baru, peserta didik saling berbagi informasi yang telah didapatkan dari pasangan sebelumnya yakni transfer pengetahuan. Adanya pergeseran pasangan diskusi maka peserta didik tidak hanya memperoleh informasi dari guru dan kelompoknya, tetapi juga dari kelompok lain sehingga pertukaran informasi semakin sering dan interaksi yang terjadi antara peserta didik juga semakin besar. Istarani (2011) mengatakan bahwa semakin besar interaksi peserta didik, maka dapat memperkaya pengetahuan yang dimiliki peserta didik. Isjoni (2009) mengajatakan bahwa interaksi dan komunikasi yang berkualitas dapat meningkatkan prestasi belajar peserta didik. Diakhir pertemuan evaluasi diberikan kepada peserta didik dan dikerjakan secara individu secara jujur untuk mengetahui pemahaman peserta didik terhadap materi yang telah dipelajari.

Dari pengamatan yang telah dilakukan peneliti selama penelitian, keaktifan peserta didik dapat terlihat jelas ketika peserta didik mencari jawaban dengan pasangan masing-masing, mereka terlihat kompak dan saling bekerjasama. Hal ini merupakan suatu ciri dari pembelajaran kooperatif seperti yang dijelaskan oleh Anita Lie (2008), pembelajaran kooperatif merupakan pembelajaran yang menitikberatkan pada gotong royong dan kerjasama kelompok.

Kendala yang dihadapi saat melakukan penelitian yakni Sebagian peserta didik kurang memahami langkah-langkah yang harus dilakukan pada proses pembelajaran, 
peserta didik belum terbiasa dengan model pembelajaran kooperatif bamboo dancing sehingga menyebabkan beberapa peserta didik kebingungan pada saat melakukan pergeseran pasangan pada saat diskusi kelompok. Oleh karena itu, pengajar harus membimbing peserta didik saat melaksanakan pembelajaran sehingga proses pembelajaran sesuai dengan waktu yang telah ditentukan. Kendala lain yakni saat berdiskusi peserta didik agak ribut mendiskusikan jawaban soal yang diberikan, sehingga untuk mengatasinya pengajar harus mengawasi dan membimbing kelompok agar tidak terjadi keributan dan pada akhirnya diskusi berjalan dengan lancar.

\section{SIMPULAN}

Penerapan model pembelajaran kooperatif bamboo dancing dapat meningkatkan hasil belajar peserta didik dengan hasil nilai post test kelas eksperimen 72,27 dan kelas kontrol sebesar 64,21. Dan hasil uji t-independen 0,01 kelas ekperimen dan 0,02 di kelas kontrol (sig<0,05) $\mathrm{H}_{0}$ ditolak dan $\mathrm{H}_{1}$ diterima.

\section{DAFTAR RUJUKAN}

Anita Lie. 2008. Cooperative Learning ; Mempraktikkan Cooperative Learning di Ruang-ruang Kelas. Jakarta : Grasindo.

Dimyati dan Mudjiono. 2006. Belajar dan Pembelajaran. Jakarta: PT Rineke Cipta.

Isjoni. 2009. Cooperative Learning; Efektivitas Pembelajaran Kelompok. Yogyakarta :Pustaka Pelajar. Istarani, 2011. 58 Model Pembelajaran Inovatif (Reverensi Guru Dalam Menentukan Model Pembelajaran). Medan: Media Persada.

Istarani. 2014. 58 Model Pembelajaran Inovatif. Medan : Media Persada.

Made Wena. 2010. Strategi Pembelajaran Inovatif Kontemporer; Suatu Tinjauan Konseptual Operasional. Jakarta : Bumi Aksara.

Miterianifa. 2013. Strategi Pembelajaran Kimia. Jakarta : Pustaka Mulya.

Sari, S. A., Akhyar, O., \& Wardhani, R. A. (2018). Analisis Keefektifan Strategi Pembelajaran True or False dan Take and Give Terhadap Hasil Belajar Siswa pada Materi Asam Basa Kelas XI SMA Negeri 1 Alalak. Dalton: Jurnal Pendidikan Kimia dan Ilmu Kimia, 1(1), 1-10.

Shoimin, A. (2014). Model Pembelajaran Pendidikan dan Pengembangan. Jakarta: Prenada Media Group.

Sukarsih, N. K., Wardhani, R. A., \& Mashuri, M. T. (2018). Pengembangan Kartu Remi Kimia Menggunakan Model Pembelajaran TGT (Teams Games Tournament) Terhadap Hasil Belajar Siswa Pada Materi Pokok Sistem Koloid Kelas XI SMA KORPRI Banjarmasin. Dalton: Jurnal Pendidikan Kimia dan Ilmu Kimia, 1(1), 16-22.

Syaiful Bahri Djamarah dan Aswan Zain. 2010. Strategi Belajar Mengajar. Jakarta : Rineka Cipta.

Wina Sanjaya. 2009. Strategi Pembelajaran Berorientasi Standar Proses Pendidikan. Jakarta : Kencana Prenada Media Group. 